\title{
Communicating Culture: An Exploratory Study of the Key Concepts in Maori Culture on Maori Web Sites
}

\author{
Zlatko J Kovacic \\ The Open Polytechnic of New Zealand, New Zealand
}

KovZla@topnz.ac.nz

\begin{abstract}
We examine how accurately the belief system or cultural concepts of Maori, the indigenous people of New Zealand, is reconstructed in the virtual world of the Internet. Nine Maori web sites were searched using a list of 44 key concepts in Maori culture. We registered how many pages within a particular web site contain each of the key concepts. These numbers were set up in a data matrix for further statistical analysis. The Multidimensional Scaling method was used to construct a spatial representation of Maori web sites in the space generated by the key concepts in Maori culture. Using the correlation coefficients between derived dimensions and the key concepts we interpreted three dimensions as General Cultural, Intra-tribe Dynamics and Educational. The position of each Maori web site in this space has been located and described.
\end{abstract}

Keywords: Maori Culture, Web Sites, Internet, New Zealand, Multidimensional Scaling

\section{Introduction}

The explosive growth of the Internet creates an opportunity for different ethnic groups to communicate their cultural values to a worldwide audience. Maori, the indigenous people of New Zealand, use the Internet in different ways: to promote their cultural values, to teach young Maori language, spiritual and ethical values and social rules of conduct and to present relevant facts and databases to support their claim for land and natural resources. Internet tools are also used to promote Maori enterprises in the global economy (Maori e-commerce sites) and for communication between members of tribes and others interested in Maori issues. However, the Internet poses some threats to the cultural values of Maori people, as discussed by Smith (1997). Modern technology allows to anyone to easily reproduce and disseminate digital images and documents on the Internet and that raises concern with Maori that their heritage for example, the digital images of their ancestors or face tattoos (Moko), will be exploited and sold. This could be viewed as culturally offensive since Maori place great importance on the concept of cultural property (the

Material published as part of this journal, either on-line or in print, is copyrighted by the publisher of Informing Science. Permission to make digital or paper copy of part or all of these works for personal or classroom use is granted without fee provided that the copies are not made or distributed for profit or commercial advantage AND that copies 1) bear this notice in full and 2) give the full citation on the first page. It is permissible to abstract these works so long as credit is given. To copy in all other cases or to republish or to post on a server or to redistribute to lists requires specific permission and payment of a fee. Contact Editor@inform.nu to request redistribution permission. rights of cultural and ethnic groups to control of the knowledge and information created over generations by the group).

The question we are interested in is how well Maori web sites actually reflect Maori culture in this new environment, i.e. in the virtual world of the Internet? Is there a correspondence between the oral (very important in Maori tradition), written and virtual worlds? If a correspondence exists then we can say that the Maori community has been re-constructed in the virtual world. Another set of questions is related to Maori web sites design. Although some authors, such as Benton (1996) takes marae - one of the key Maori cultural concepts - as a metaphor and relates it to a certain Internet tool - discussion forum, so far there have been few attempts to recognise Maori cultural concepts and relate them to the elements or tools in the virtual world (see Kovacic, 2001). (Benton (1996, p. 136) says that the message section is the marae of Te Wahapu (communications system launched in 1990 in New Zealand).)

However, it is not just a matter of using Maori themes or how the site displays Maori art forms, but more importantly how the whole concept of the site design (that is particularly important for an educational site) is embodied in 'te ira tangata' (the life principle of people), which is the essence of Maori knowledge. (Tangaere (1997) made an attempt toward establishing Maori human development learning theory. According to him, to be able to socialise in a particular manner within a Maori context a person has to use the appropriate language and the entire interaction should be based on the customs, value and tradition. "This is known in Te Kohanga Reo and Kura Kaupapa Maori as 'Te Aho Matua', the philosopical 
body of knowledge which bonds us to our ancestors, the land, the universe, and Io Matua Kore (God).") Also, how have the Internet technologies been used to build a Maori web site which follows the tradition of tribe rituals and communications, or which incorporates the specific approach Maori have taken in transferring knowledge to the younger generation? (Cormack (1996, p. 163) uses the axiom of Maori social dynamics "groups compete, individuals co-operate" to build appropriate and effective learning environment for Maori students.) In this paper we made an attempt to provide some answers to these questions. Analysis at this stage is exploratory in nature and we consider it as the first step toward deep linguistic and semantic analysis of Maori web sites when a contextual analysis of each site would be applied.

The Multidimensional Scaling method has been used to analyse a data set and create a perceptual map. The relevance of our results are threefold. Firstly, using this map we provide a picture of how the web sites are associated with key cultural concepts. Secondly, the map shows where the sites are located within a set of Maori web sites on the Internet. Thirdly, it gives suggestions as to which elements (key concepts) the web site author should include on the web site to change the position of their site, moving the site on the perceptual map closer to or away from the other Maori web sites.

\section{Notes About Key Concepts in Maori Culture}

Cross-cultural understanding is not only about knowing the meaning of a single word or phrase from another language but more about an essential understanding of the spiritual components and every day rituals and behaviour. These rituals are deeply rooted in the tribe's or ethnic group's tradition and constitute the identity of the tribe. Therefore, a cross-cultural understanding should be based on a more holistic approach.

This is particularly true for an understanding of Maori culture. Even a single word or thing in every day use may have a different meaning, or place in a tribal ceremony or even become a spiritual component during certain rituals.

Take Hangi (translated as Earth Oven) as an example. Someone would simply describe hangi as a traditional way of cooking food among people in Polynesia. The following very picturesque description of a hangi is given by Barlow (1994, p. 19): "The hangi consists of a shallow hole dug in the ground. A fire is prepared in the hole and stones are placed on the top of it. When the stones are hot the hangi is prepared for cooking by leaving the hot stones and some of the coals at the bottom of the hole. The food is placed on top of the stones, the meat first, with the vegetables, such as kumara and potatoes, on top of it. The hangi is then covered with leaves or mats woven out of flax and left to cook. Soil is usually heaped over the mat cover to keep the heat in."

Apart from this everyday use, hangi has it own spiritual place in the Maori rituals. For example hangi has its own place in a ritual for opening a new house, or at harvest time. As Barlow (1994, p. 19) explains: "For these rituals, kumara (sweet potatoes) were cooked in the hangi because it is believed that cooked food has the power to disperse tapu (or sacred, set apart). Through the process of cooking in the hangi the essence of the food ascends to the gods, thus rendering the food useless and devoid of the power to reproduce. This may be the derivation of the word, hangi: the food is roasted so that the ha (or life essence) is released and the remainder is rendered devoid of its goodness as a living entity."

In Figure 1 we illustrate the place of the hangi in Maori rituals. A hangi, is an earth oven used on marae (community facilities). Usually it is prepared and managed by rangatahi (young people) while kaumatua (respected elders) direct and organise them. During the preparation process aroha (love) is shown by the kaumatua and rangatahi for the reputation or mana of their people and iwi (tribe) as well as that of the visitors. Manaaki is shown by offering of food as hospitality to the visitors - the meal prepared in the hangi and eaten during the visit is called a hakari or feast. By taking part in the hakari and eating the hangi the difference between tapu of the visitor group and home group is mitigated. Although an oversimplification, we could say that all the prayers and rituals conducted in Maori ceremonies demonstrate a desire to placate the gods. Therefore a spiritual component and overall unity of living creatures and all other things on Earth are very important in Maori culture. In other words, we could say that everything has tapu simply because everything was created by Io (Supreme God).

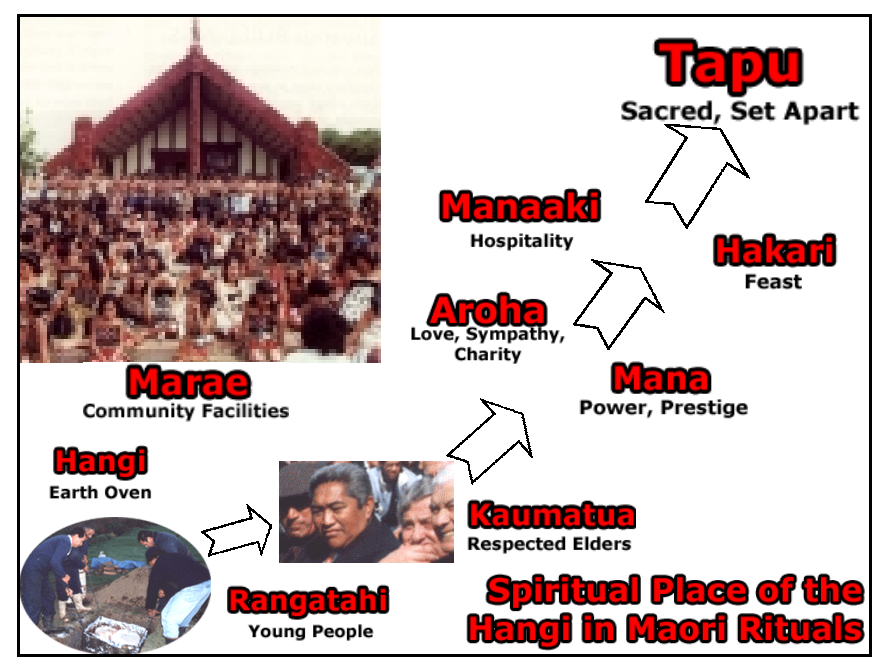

Figure 1: Spirituality of the Hangi in Maori Rituals 
Hangi is used as an example to illustrate the depth of meaning of a single word to Maori. We would like to emphasise the exploratory scope of our approach, considering it as the first step towards a deeper linguistic and semantic analysis.

\section{Data}

Nine Maori web sites were analysed (see Appendix, Table B). The web sites were selected non-randomly to cover a broad range of topics from news, informational, cultural, tribal, political and educational and limited only to those web sites where a search site facility was available.

Key concepts were also selected non-randomly to cover a broad range of areas commonly addressed in major books of Maori culture or specific to their heritage. One should, therefore, interpret the findings only as clues to grasping Maori culture. Throughout this paper we refer to the 44 Maori cultural concepts mainly identified by Barlow (1994) and King (1992) as key concepts (see Appendix, Table B).

Our data matrix has 9 rows (web sites) and 44 columns (key concepts). Each cell in data matrix is a number that tells us how many pages within particular web site contain a specified key concept. We may interpret these numbers as revealed preferences of the web site author, the same way as we might treat consumer preferences in regard to a specific product in marketing research. In other words, if a concept could be found more often than other concepts it will mean that the web site has been built to emphasise a certain aspect of the Maori culture. For example, if concepts such as Akoranga, Kohanga Reo, Rangatahi, Wananga and Whare Wananga are found more frequently than other concepts then probably the web site is an educational site, or it discusses educational issues in greater scope than any other issue.

What do concepts such as Manuhiri, Marae, Tapu, Karanga, Powhiri, Wero and Hongi have in common? They are all elements of the marae protocol and therefore could be found on an informational web site that explains Maori ceremony.

These two examples illustrate what we expect apriori, before we start with our analysis. Some of the key concepts will tend to group together with other concepts because of their common semantic background. Therefore we expect to find the same number of occurrences for each subset of concepts. Furthermore this will make the interpretation of derived dimensions easier.

Since the numbers of pages in these sites are quite different we have transformed the original data by dividing numbers in each row with the maximal number of pages for the particular site. This transformation preserves a site's internal structure, bringing unequal sized sites on the equal footing and making them comparable with other sites.

\begin{tabular}{|l|ccc|}
\hline Web site & Dimension 1 & Dimension 2 & Dimension 3 \\
\hline Culture & -0.97 & 0.98 & 0.06 \\
Maorinews & 0.25 & -0.68 & 0.25 \\
Maaori & -0.30 & 0.04 & 0.45 \\
Maori.org & 2.71 & 0.83 & 0.13 \\
Waitangi & -0.43 & -0.39 & 0.30 \\
Iwidex & -0.78 & 0.27 & 0.13 \\
Kohanga & -0.05 & -0.08 & -1.48 \\
Aotearoa & 0.67 & -1.21 & 0.06 \\
Ngaitahu & -1.10 & 0.25 & 0.10 \\
\hline
\end{tabular}

Table 1: Coordinates for the First Three Dimensions

\section{Methodology}

The method used in this paper belongs to the body of multivariate statistical methods known as Multidimensional Scaling (usually abbreviated to MDS). MDS is an exploratory technique used to uncover the "hidden structure" of a set of data. MDS enables us to represent the dissimilarities (distances) between entities (objects) spatially as in a map, i.e. allows us to make a picture of the information in the data. Dissimilarities are any set of numbers that express the amount of differences between pair of entities. Entities can be any objects or events. MDS map the entities in a multidimensional space (usually 2 to 3 dimensional space) in such way that their relative positions in the space reflect the degree of perceived dissimilarity between the entities. Interpretation of the dimensions can lead to an understanding of the processes underlying the perceived differences of entities. That allows the researcher to explain observed distances between entities in terms of derived dimensions.

When MDS is applied two problems have to be solved. First, the researcher has to choose how many dimensions to keep for further analysis and second, how to interpret derived dimensions. We discuss both issues in the next section. In this paper we used a classical metric MDS. For the full discussion of this and other MDS methods see Cox and Cox (1994).

\section{Results}

The MDS analysis begins with the squared Euclidean distance matrix, based on the data matrix described in Data section. The objective is to use a metric MDS to derive a spatial representation for the nine Maori web sites. The original observations will then be used to provide an interpretation for the derived dimensions. In MDS the objectives include minimising 
the number of dimensions while at the same time preserving the dissimilarity relationships of the original dissimilarity matrix. Often only two dimensions are used. A measure that is commonly used to determine goodness of fit is called stress. MDS theory says that the stress value of the solution should be less than 0.10 . With dimensionality of 3 stress value in our example is quite high (0.198). We may reduce it to $10 \%$ if we include an additional, fourth dimension in our solution. At the same time a common rule of thumb is to require that the number of web sites should exceed (4p-1), where $\mathrm{p}$ is dimensionality. If we accept the four-dimensional model then the number of web sites should exceed 15. Therefore, at this stage, we made a compromise using three-dimensional solution in further analysis.

In addition to the 44 key concepts, the extent to which a web site author has adopted "all" possibilities offered by the technology has been measured. For example: including ecommerce components, sitemap, mailing list, guestbook, etc. (see the last column in the table in Appendix B).

Figure 2 shows spatial plots for the first three dimension based on data from Table 1.

To provide some interpretation for the derived dimensions, a correlation matrix was generated to relate the three dimensions to the 44 variables (key concepts). As there are only a small number of observations, large correlations are required to feel confident about the relationships. In Table 2 only statistically significant correlation coefficients at the 5 percent level are shown. We include a few other large, although insignificant coefficients in brackets. We use them to give a meaningful interpretation of the three generated dimensions.

By inspection of the correlation coefficients in the second column in Table 2 it would appear that Dimension 1 is strongly positively related with most of the key concepts in Maori culture. Therefore we have labeled it General Cultural Dimension (or Spiritual Dimension).

Dimension 2 is strongly related to Kaumatua (respected elder), Kuia (elderly women), Rangatahi (young generation) and Kotahitanga (tribal unity). Correlation coefficients for Hapu (sub-tribe) and Iwi (tribe) are close to becoming significant at 5\% level. On the other side, positive although statistically insignificant correlation coefficients exist for Maramataka (monthly calendar), Pounamu (greenstone) and Hangi (earth oven). Taking all these key concepts into account we have labeled Dimension 2 as the Intra Tribe Dynamics Dimension.

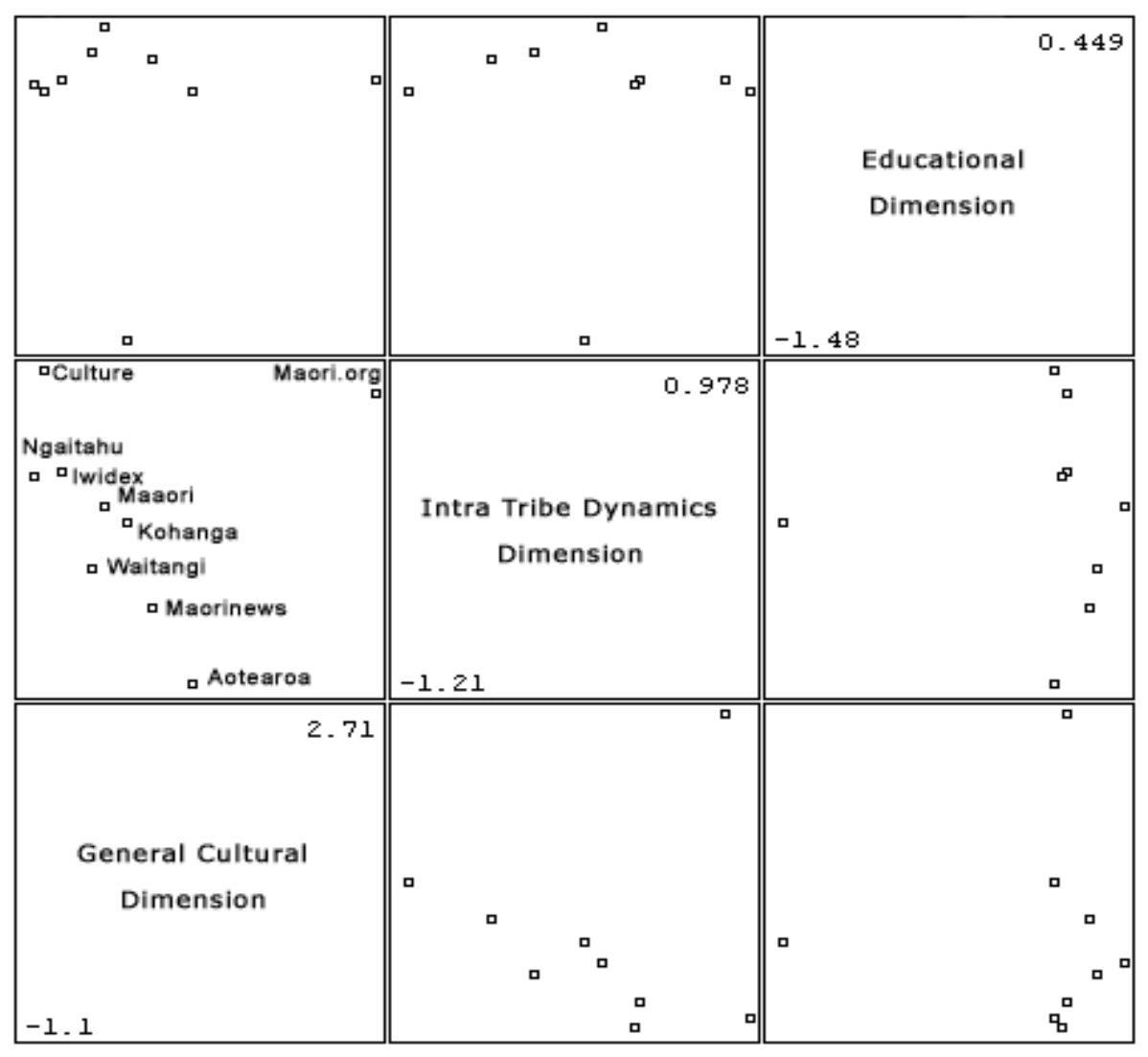

Figure 2: Spatial Plot for the First Three Dimensions
Finally, for Dimension 3 the only significant correlation coefficient is with Akoranga (teachings). Negative correlation coefficients are for Kohanga Reo (language nest) and Whaikorero (formal speech making) and positive for Whakapapa (genealogy), Hapu (sub-tribe) and Whare Wananga (place of learning). All these key concepts are related to the traditional teachings of a tribe covering both spiritual values and social behavior handed down by tribal elders to succeeding generation. Therefore we have labeled Dimension 3 as Educational Dimension.

We may trace the position of each web site on the spatial plot. For example, www.maori.org.nz and www.culture.co.nz web sites provide some insights into the horizontal dimension labeled General Cultural Dimension, because they are located on the opposite ends of horizontal axis. If we move along the second axis (Intra Tribe Dynamics Dimension) we may notice that both www.maori.org.nz and www.culture.co.nz web sites are on the opposite end compare to the 


\begin{tabular}{|c|c|c|c|}
\hline Key Concept & Dimension 1 & Dimension 2 & Dimension 3 \\
\hline Akoranga & & & -0.93 \\
\hline Aroha & 0.96 & & \\
\hline Atua & 0.81 & & \\
\hline Hakari & 0.87 & & \\
\hline Hangi & 0.83 & $(0.51)$ & \\
\hline Hapu & & $(-0.69)$ & $(0.47)$ \\
\hline Hongi & 0.72 & & \\
\hline Iwi & 0.71 & $(-0.61)$ & \\
\hline Kaitiaki & 0.94 & & \\
\hline Karanga & 0.91 & & \\
\hline Kaumatua & & -0.85 & \\
\hline Kaupapa & 0.77 & & \\
\hline Kawe Mate & 0.89 & & \\
\hline Koha & 0.94 & & \\
\hline Kohanga Reo & & & $(-0.69)$ \\
\hline Kotahitanga & & -0.72 & \\
\hline Kuia & & -0.74 & \\
\hline Mana & 0.74 & & \\
\hline Manaaki & & & \\
\hline Manuhiri & 0.87 & & \\
\hline Marae & & & \\
\hline Maramataka & & 0.74 & \\
\hline Moko & 0.86 & & \\
\hline Pare Kawakawa / & & & \\
\hline Taua & & & \\
\hline Piupiu & 0.89 & & \\
\hline Poi & 0.91 & & \\
\hline Pounamu & & $(0.70)$ & \\
\hline Powhiri & 0.91 & & \\
\hline Rahui & & & \\
\hline Rangatahi & & -0.72 & \\
\hline Reo Maori & 0.85 & & \\
\hline Runanga & & & \\
\hline Tangihanga & 0.88 & & \\
\hline Taniko & 0.84 & & \\
\hline Tapu & 0.88 & & \\
\hline Tiriti o Waitangi & & & \\
\hline Wairua & 0.99 & & \\
\hline Wananga & & & \\
\hline Wero & 0.95 & & \\
\hline Whaikorero & & & $(-0.61)$ \\
\hline Whakapapa & & & $(0.48)$ \\
\hline Whanau & 0.73 & & \\
\hline Whare Wananga & & & $(0.43)$ \\
\hline Whare Whakairo & & & \\
\hline
\end{tabular}

Table 2: Correlation Matrix Relating Dimensions to Key Concepts in Maori Culture

Aotearoa.wellington.net.nz site. Since this dimension is highly negatively correlated with those key concepts which describe tribal unity and a strong feelings and pride of being a member of a distinct tribe or sub-tribe it is understandable why the
Aotearoa.wellington.net.nz site is positioned aside from the rest of the web sites. This site is dedicated to the problems and issue of Maori self-determination and these are the key concepts that give this web site a distinct character.

We may have a similar reflection about $w w w . k o h a n g a . a c . n z$ web site in regard to the third dimension because of a distinctive position this web site has in respect to other web sites (single point at the bottom of the diagram in the first cell in Figure 2).

\section{Concluding Remarks}

This paper has shown the result of an exploratory statistical analysis of the key concepts in Maori culture presented on the Internet. Even with a small-scale data set of nine Maori web sites we have demonstrated the usefulness of the spatial presentation of Maori web sites in the space generated by the key cultural concepts.

More specifically, we have found that Multidimensional Scaling can be used in an effective manner to display each web site in low-dimensional space. Three dimensions derived from 44 key concepts are: General Cultural, Intra-tribe Dynamics and Educational.

The position of each web site in such a space could carry useful information from cultural or lucrative point of view. If the site discusses very few cultural concepts it is probably dedicated to a specific topic and therefore would be interesting to only a small segment of highly profiled visitors. From the business point of view, position of the web sites in this space, gives marketers an idea of which sites are relevant to them in regard to the visitors demographics. An appropriate ad banner could be placed on this site targeting visitors interested in a specific topic (education, for example).

Further work is planned to extend the data set used in this analysis. We also plan to use a survey to investigate the perceptions that visitors to Maori web sites have about the web sites in regard to the presentation of Maori cultural values.

\section{References}

Barlow C. (1994). Tikanga Whakaaro - Key Concepts in Maori Culture, Auckland: Oxford University Press.

Benton R. (1996). Liberation and Revitalization: Computer-Based Information Systems and the Maori Language Renaissance, Ch. 7 in Words Have Wings - Teaching and Learning with Computer Networks, ed. Kwok-Wing Lai, Dunedin: University of Otago Press. 
Cormack I. (1997). Creating and Effective Learning Environment for Maori Students, Ch. 11 in Mai i Rangiatea, eds. Te Whaiti P., McCarthy M. and Durie A., Auckland: Auckland University Press, 163-169.

Cox T. F. \& Cox M. A. A. (1994). Multidimensional Scaling. London: Chapman \& Hall.

King M. (ed.) (1992). Te Ao Hurihuri - Aspects of Maoritanga, Auckland: Reed Publishing Group.

Kovacic Z. (2001). e-Marae - Virtual Maori Community Facilities, Working Paper, Lower Hutt: The Open Polytechnic of New Zealand.

Smith A. (1997). Fishing with New Nets: Maori Internet Information Resources and Implications of the Internet for Indigenous Peoples, Accessed November 28, 2000 at

http://www.isoc.org/isoc/whatis/conferences/inet/97/proceedings/E 1/E1_1.HTM
Tangaere A. R. (1997). Maori Human Development Learning Theory, Ch. 4 in Mai i Rangiatea, eds. Te Whaiti P., McCarthy M. and Durie A., Auckland: Auckland University Press, 46-59.

\section{Acknowledgement}

The author would like to thank Wayne Pihema (School of Business and Public Management, Victoria University, Wellington, New Zealand) for important discussion of Maori cultural concepts presented in this paper. The author would also like to thank John Steven Green (School of Information Science and Humanities, The Open Polytechnic of New Zealand, Wellington, New Zealand) for valuable comments on the first draft of this paper presented in the 2001 Informing Science Conference in Cracow, Poland in 19-22 June 2001.

\section{Appendix}

\begin{tabular}{|c|c|c|c|}
\hline Maori & English & Maori & English \\
\hline Akoranga & Teachings & Moko & Tattoo \\
\hline Aroha & Love, Sympathy, Charity & Pare Kawakawa / Taua & Chaplet \\
\hline Atua & Gods & Puipui & Decorative Skirt \\
\hline Hakari & Community Feast & Poi & $\begin{array}{l}\text { Ball on String; Dancing } \\
\text { Aid }\end{array}$ \\
\hline Hangi & Earth Oven & Pounamu & Greenstone (Jade) \\
\hline Hapu & Sub-tribe, Clan & Powhiri & Welcome Ceremony \\
\hline Hongi & Salutation & Rahui & $\begin{array}{l}\text { Protection, Restriction, } \\
\text { Conservation }\end{array}$ \\
\hline Iwi & Tribe & Rangatahi & The Young Generation \\
\hline Kaitiaki & Guirdian & Reo Maori & Maori Language \\
\hline Karanga & Welcome Call & Runanga & $\begin{array}{l}\text { Board, Committee, Coun- } \\
\text { cil }\end{array}$ \\
\hline Kaumatua & Respected Elders & Tangihanga & Funeral Ceremony \\
\hline Kaupapa & $\begin{array}{l}\text { Policy, Rules of Opera- } \\
\text { tion }\end{array}$ & Taniko & Fine Decorative Weave \\
\hline Kawe Mate & Memorial Service & Tapu & Sacred, Set Apart \\
\hline Koha & $\begin{array}{l}\text { Donation, Gift, Contribu- } \\
\text { tion }\end{array}$ & Tiriti o Waitangi & Treaty of Waitangi \\
\hline Kohanga Reo & Language Nests & Wairua & Spirit \\
\hline Kotahitanga & Tribal Unity & Wananga & Esoteric Learning \\
\hline Kuia & Elderly Women & Wero & Ritual Challenge \\
\hline Mana & $\begin{array}{l}\text { Power, Authority, Pres- } \\
\text { tige }\end{array}$ & Whaikorero & Formal Speech-making \\
\hline Manaaki & Hospitality & Whakapapa & Genealogy \\
\hline Manuhiri & Visitors & Whanau & $\begin{array}{l}\text { Family (immediate and } \\
\text { extended) }\end{array}$ \\
\hline Marae & Community Facilities & Whare Wananga & Place of Learning \\
\hline Maramataka & Monthly Calendar & Whare Whakairo & Carved Ancestral House \\
\hline
\end{tabular}

Table A: Key Concepts in Maori Culture 


\begin{tabular}{|c|c|c|c|c|}
\hline Abbreviation & URL & Description & $\begin{array}{l}\text { Business } \\
\text { Model }\end{array}$ & Features \\
\hline Culture & www.culture.co.nz & $\begin{array}{l}\text { An exhibit of Maori cultural ex- } \\
\text { pression. Site. Information and } \\
\text { links on Maori, Maori culture, } \\
\text { tattoo, art, language, history, wars, } \\
\text { legends, women, haka, education } \\
\text { and music. }\end{array}$ & Portal & $\begin{array}{l}\text { Local search, naviga- } \\
\text { tion system, newslet- } \\
\text { ter, mailing list, email } \\
\text { link, visitors feed- } \\
\text { back, message board }\end{array}$ \\
\hline Maorinews & maorinews.com & $\begin{array}{l}\text { Maori portal, news, views, com- } \\
\text { mentary and other writings. }\end{array}$ & Portal & $\begin{array}{l}\text { Local search, naviga- } \\
\text { tion system, mailing } \\
\text { list, email link }\end{array}$ \\
\hline Maaori & maaori.com & $\begin{array}{l}\text { Maori people of Aotearoa / New } \\
\text { Zealand: from Hawaiki to Ha- } \\
\text { waiki. Their culture, history, my- } \\
\text { thology, legend and genealogy. }\end{array}$ & Info & $\begin{array}{l}\text { Local search, email } \\
\text { link, guestbook }\end{array}$ \\
\hline Maori.org & www.maori.org.nz & $\begin{array}{l}\text { The world wide web of Maori } \\
\text { Organisations of New Zealand } \\
\text { (www.maori.org.nz). This is a site } \\
\text { for information on matters Maori. }\end{array}$ & Portal & $\begin{array}{l}\text { Online selling, pur- } \\
\text { chasing \& paying, } \\
\text { local search, sitemap, } \\
\text { navigation system, } \\
\text { mailing list, email } \\
\text { link, visitors feed- } \\
\text { back, message board, } \\
\text { guestbook }\end{array}$ \\
\hline Waitangi & $\begin{array}{l}\text { www.waitangi- } \\
\text { tribunal.govt.nz }\end{array}$ & $\begin{array}{l}\text { Government web site related to } \\
\text { work of the Waitangi Tribunal. }\end{array}$ & Database & $\begin{array}{l}\text { Local search, naviga- } \\
\text { tion system, email } \\
\text { link }\end{array}$ \\
\hline Iwidex & $\begin{array}{l}\text { www.akcity.govt.nz/library/m } \\
\text { aori/iwidex.html }\end{array}$ & $\begin{array}{l}\text { An index to the sources of infor- } \\
\text { mation on tribal history, tikanga- } \\
\text { a-iwi, and whakapapa held in the } \\
\text { Heritage and Research Collec- } \\
\text { tions of Auckland City Libraries. }\end{array}$ & Database & $\begin{array}{l}\text { Local search, sitemap, } \\
\text { navigation system, } \\
\text { email link, visitors } \\
\text { feedback }\end{array}$ \\
\hline Kohanga & www.kohanga.ac.nz & Te Kohanga Reo trust web site & Info & $\begin{array}{l}\text { Local search, email } \\
\text { link }\end{array}$ \\
\hline Aotearoa & aotearoa.wellington.net.nz & $\begin{array}{l}\text { Maori independence information } \\
\text { on Tino Rangitiritangi - Maori } \\
\text { self-determination }\end{array}$ & $\begin{array}{l}\text { Info - Po- } \\
\text { litical }\end{array}$ & $\begin{array}{l}\text { Local search, sitemap, } \\
\text { navigation system, } \\
\text { mailing list, email } \\
\text { link, visitors feed- } \\
\text { back, guestbook }\end{array}$ \\
\hline Ngaitahu & www.ngaitahu.iwi.nz & Ngaitahu tribe web site & Info - mix & $\begin{array}{l}\text { Online selling, pur- } \\
\text { chasing \& paying, } \\
\text { local search, sitemap, } \\
\text { navigation system, } \\
\text { email link, visitors } \\
\text { feedback, guestbook }\end{array}$ \\
\hline
\end{tabular}

Table B: Web Sites Related to Maori People 